
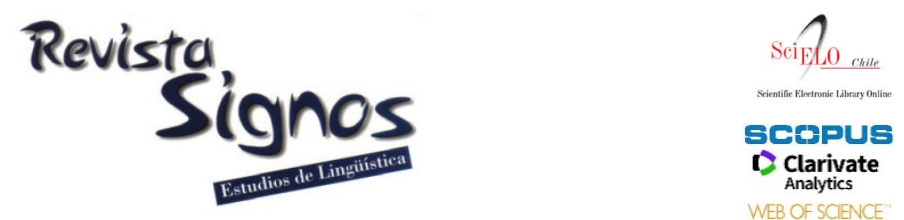

\title{
Exploring the Interaction of EFL Student Writers with SFL-based Teaching and Teacher- written Feedback
}

\author{
Investigación sobre la interacción de los estudiantes con la \\ enseñanza basada en la SFL y con retroalimentaciones por \\ escrito del maestro
}

\author{
Xiaodong Zhang \\ BEIJING FOREIGN STUDIES UNIVERSITY \\ CHINA \\ zxdman588@gmail.com
}

Recibido: 31-VIII-2019 / Aceptado: 23-XI-2020

DOI: $10.4067 /$ S0718-09342021000200465

\begin{abstract}
This case study explored how student writers interact with teaching based on systemic functional linguistics (SFL) and with teacher-written feedback. The data used in the study consisted of English-as-a-foreign-language (EFL) students' interviews, written documents, and teacher-written feedback collected at a Chinese university writing classroom over one academic year. The qualitative analysis of the study data showed that through the instruction of SFL, the students came to understand and practice writing as a meaning-making process although their understanding and practice of such were constrained by diverse factors (e.g., the difficulty of the new knowledge and genrespecific demands). More importantly, the SFL-based teacher-written feedback gradually helped enhance the students' understanding of SFL's meaning making as well as their follow-up management of contextually appropriate language resources in refining their written compositions. The study concluded that despite the challenges involved, integrating SFL-based teaching with teacher-written feedback seemed to help the students in the study re-conceptualize their writing and navigate writing effectively as a meaning-making process.
\end{abstract}

Key Words: Systemic functional linguistics, teacher-written feedback, academic writing, meaning making. 


\section{Resumen}

En el presente estudio se investigó la forma en que los estudiantes interactuaban con la enseñanza basada en la lingüística funcional sistémica (SFL) y con las retroalimentaciones por escrito del maestro. Los datos utilizados en el presente estudio consistieron en entrevistas con estudiantes de inglés como lengua extranjera (EFL), documentos escritos y retroalimentaciones por escrito del maestro reunidos durante un año académico en la clase de redacción en una universidad de China. El análisis cualitativo de los datos del estudio indicó que, bajo la orientación de la SFL, los estudiantes empezaron a comprender y practicar la escritura como un proceso de creación de significado, a pesar de que su comprensión y práctica se vieron limitados por diversos factores (por ejemplo, la dificultad de adquirir nuevos conocimientos y demandas específicas). Lo que es más importante, las retroalimentaciones presentadas por escrito del maestro basadas en la SFL ayudaron gradualmente a mejorar la comprensión de los estudiantes sobre la creación de significado de la SFL, así como su gestión de seguimiento de los recursos lingüísticos contextualmente apropiados para refinar sus composiciones escritas. El presente estudio llegó a la conclusión de que, a pesar de los problemas, parecía que la combinación de la enseñanza basada en la SFL y las retroalimentaciones escritas del maestro ayudaron a los estudiantes a reconceptualizar su escritura y orientarla a un proceso de creación de significado.

Palabras Clave: Lingüística funcional sistémica, retroalimentaciones por escrito del maestro, escritura académica, creación de significado.

\section{INTRODUCTION}

For students to produce high-quality academic writing, teachers need to teach them about meaning making, which necessitates knowledge about the close relationship between contextually relevant linguistic resources (i.e., grammar and vocabulary) and meaning representation (i.e., content) (Schleppegrell, 2004). For example, the use of modal verbs as linguistic resources is contingent on the immediate context where the meaning will be expressed: if a weak tone is intended for the audience, modal verbs with weak semantic loads must be chosen (Humphrey \& Macnaught, 2016). Indeed, research has demonstrated that an explicit teaching of writing as a meaning-making process is helpful in improving students' writing (Harman, 2018). The attempts to develop students' knowledge of meaning making, however, have centered on teacher-student verbal interactions that generally occur in the classroom (O’Hallaron, Palincsar \& Schleppegrell, 2015).

Meanwhile, teacher-written feedback (i.e., teachers' written comments on students' written compositions) has been acknowledged as a useful out-of-class tool that helps students get acquainted with effective mechanisms for good writing, enhances the knowledge about writing that students have gained in class, and develops their skill of independent regulation (Hyland \& Hyland, 2006). However, teacher-written feedback has mostly focused on correcting students' language form errors (i.e., morphosyntactic errors, such as the inappropriate use of tense or errors in subject-verb agreement), especially in the context of the teaching of English as a foreign language (EFL) (Lee, 
2017), such as among Chinese students (Zhang, 2017) and Latin American students (Taylor, Sánchez, Luzuriaga, Podestá \& Furman, 2020). This may be attributed to the limitations of the current teacher education programs, which do not promote among teachers the importance of teacher-written feedback that highlights writing as a meaning-making process. Indeed, the use of teacher-written feedback has been found to exist largely in EFL contexts, where high-stakes tests favor the accuracy of language form and teachers generally teach writing and provide written feedback at the level of language form to their students (Lee, 2017; Zhang, 2017).

As shown in the foregoing, it is important that teachers teach students about writing as a meaning-making process while giving them the corresponding written feedback, enabling students to gradually develop into independent and proficient writers (Hughes, 2009; Rose \& Martin, 2012). However, the research on developing students' meaning-making knowledge has been primarily focused on students' verbal interaction with their teacher (Rose \& Martin, 2012), with little attention to the role of meaning-making-based teacher-written feedback as a follow-up assistance. To fill this gap and to better help students conceptualize and improve their writing, this study aims to shed light on how students interact with meaning-making knowledge and the corresponding teacher-written feedback. By doing so, it is hoped that the study will help teachers to realize the importance of revamping their writing curricula and teaching writing at the meaning-making level. The study will also help administrators to come up with teacher education programs that will adequately prepare pre- or inservice writing teachers to become more effective writing teachers by enabling them to understand writing as a meaning-making process.

\section{Literature review}

\subsection{Writing as a meaning-making process: A systemic functional perspective}

Resonating with the demands of writing as a meaning-making process, systemic functional linguistics (SFL) highlights the dynamic relationship between contextually appropriate linguistic choices and content construction (Schleppegrell, 2004). It provides multi-layered constructs for demystifying writing (Martin \& White, 2003; Harman, 2018), offering an accessible tool for teachers to effectively teach writing to their students.

Indeed, while SFL emphasizes structural accuracy (similar to traditional grammar), it demonstrates how language is used contextually in response to the field (i.e., what the writing is about), tenor (i.e., who is involved in the writing, including its writer and audience), and mode (i.e., the way of presenting the writing) (Rose \& Martin, 2012). The three contextual variables (i.e., field, tenor, and mode) respectively relate to three meanings constituting discourse content: ideational meaning (i.e., the meaning of the 
core discourse content as well as the logical relationships between the discourse contents), interpersonal meaning (i.e., the meaning about engaging with the audience or showing evaluative stances), and textual meaning (i.e., the fluency of sentences) (Martin \& White, 2003).

More importantly, SFL also provides particular labels, illuminating how conventional language features in context are used to realize each dimension of meaning (Martin \& White, 2003; Schleppegrell, 2004; Zhang, 2018). For example, the label 'participant', similar to 'subject' or 'complement' in traditional grammar, reveals which type of noun phrases (e.g., nominalization, non-human noun phrases) are used in academic writing. SFL also provides labels to show how lexical and grammatical resources construct interpersonal meaning in different genres. For example, 'attitude' reveals that explicit (e.g., adjectives) and hidden authorial emotions/judgments (e.g., adverbs) are favored, respectively, in expository and argumentative writing. 'Engagement' is used to show the origin of information, illustrated by citations, or the reliability of information, as exemplified by modal verbs. 'Graduation' helps show the intensity of the semantic load, as illustrated by the adverbs 'much' and 'generally'. At the level of textual meaning, cohesive ties (e.g., conjunction words, lexical repetition) are also offered by SFL to illustrate how sentences are cohesively interwoven, apart from the theme pattern (e.g., the repetition of the starting point of a sentence). Notably, in SFL-based writing instruction, SFL is not used as a set of mechanical techniques for teaching students how to write. Instead, it is a theory that flexibly guides students in making appropriate choices from among their language repertoires for a given context, such as expository writing (Schleppegrell, 2004).

Empirical research has documented that students of EFL and of the English as a Second Language (ESL) program benefited from their exposure to SFL-based writing instruction (e.g., Harman, 2018; Zhang, 2018). In such studies, the researcher(s) demonstrated that students could gain meaning-making awareness and could practice writing as a meaning-making process through SFL-based writing instruction. However, researchers likewise demonstrated that students also struggle while receiving SFL-based writing instruction because of the cognitive load involved in students' task of authentically digesting SFL-related information in relation to their writing (Moore, Schleppegrell, \& Palincsar, 2018), which is aggravated by the limited class hours allocated for teacher assistance (Zhang, 2021).

\subsection{Teacher-written feedback: A systemic functional perspective}

The need for SFL-based teacher-written feedback as an additional tool to enhance students' classroom learning is obvious given that students may have limited time to fully comprehend new knowledge and may have difficulty applying the knowledge that they gained in class directly to their written compositions (Zhang, 2021). However, 
almost no research has been conducted on how teachers, in line with the SFL-based perspective on writing instruction, offer written feedback to their students despite the obvious value of teacher-written feedback as a potentially useful tool to motivate students to think and make revisions in their written composition on their own based on their teachers' comments on their work (Lee, 2017). For example, in EFL contexts, such as among Chinese and Latin American students, SFL has been promoted as a teaching praxis, but due to the dearth of teacher education programs in this area, teacher-written feedback is concentrated on the sentence level (i.e., grammar), and the practice of giving SFL-based feedback is still rare (Carlino, 2012; Taylor et al., 2020).

To help students better understand SFL and improve their writing, it will be beneficial for teachers to provide their students with written feedback connected to SFL's constructs (see also Humphrey \& Macnaught, 2016). For example, teachers can use register variables to contextualize student writing: 'mode' to remind their students to avoid fragmentary expressions in writing; 'tenor' to remind their students about the proper strategies to use in interacting with their audience; and 'field' to remind their students not to wander off from the topic. Meanwhile, teachers can remind their students about meaning making in their writing: using appropriate linguistic choices (i.e., vocabulary/grammar) in achieving the three dimensions of content (i.e., ideational meaning, interpersonal meaning, and textual meaning) for different types of writing. For example, teachers can remind their students of the choice of proper modal verbs or evaluative words at the interpersonal dimension or of cohesive ties at the textual dimension. In sum, integrating SFL-based teaching and teacher-written feedback may be very useful in helping students improve their writing.

Considering the foregoing, it is worthwhile to investigate students' interaction with SFL-based teaching and teacher-written feedback. However, almost no such research has been conducted. To fill such research gap, this study was guided by the following two interrelated research questions in an EFL writing class over one academic year: (1) How do students interact with SFL-based writing instruction as a meaning-making process?; and (2) How do students interact with SFL-based teacher-written feedback?

\section{Methodology}

Overall, the current study adopted an exploratory qualitative case study approach (Eisner, 2017). That is, it did not focus on making generalized findings but on exploring the answers to the aforementioned research questions in an in-depth way in an EFL writing class.

\subsection{Context of the research and participants}

The study was conducted in two consecutive one-semester-long English writing courses taken over one academic year at a university in China. The first semester was 
on expository (informational) writing and the second was on argumentative writing. The writing courses were offered to students majoring in English. The students were all born and raised in China and spoke English as a foreign language. The students in the university were similar to those in larger EFL contexts: they held deep concepts related to writing, with a focus on language accuracy at the sentential level (Zhang, 2017).

Additionally, the mandatory textbooks for such courses did not have all the contents that the instructor (also the researcher) needed (i.e., an SFL-based perspective on writing as a meaning-making process) as their primary focus was on reading texts and sporadic language practices related to academic writing (e.g., the use of conjunctions to enhance textual flow). However, as materials (e.g., textbooks and online resources) are key tools for delivering discipline-specific knowledge for writing instruction (Tomlinson, 2003; Zhang, 2018), the instructor, an SFL expert, collected and organized relevant online resources (e.g., web-based texts) to supplement the contents of the mandatory textbooks for student writers, which was made possible by the abundance and accessibility of online resources on SFL-based writing instruction (Taffs \& Holts, 2013; Zhang, 2018) and by the fact that the university allowed their teachers to freely supplement their in-class teaching with the use of relevant online resources.

The online resources that were used by the instructor/researcher to develop the students' knowledge of SFL included academic papers, audio-visual resources (e.g., YouTube podcasts), and web-based texts on SFL. These resources were organized and carefully selected based on the SFL constructs (i.e., register, ideational meaning, interpersonal meaning, and textual meaning) and were then distributed to the students (see the Appendix section for the sample online resources that were used in the classroom). The students were then assigned to preview and read the materials before the corresponding content was taught in the upcoming class. In other words, these materials provided a means for the students to understand each SFL construct in relation to writing. In all, the pedagogical design and use of online resources was informed by the teacher's knowledge of SFL and by the teacher's desire to help the students develop the skills of "learning to learn" and "self-management" (GeorgeWalker \& Keeffe, 2010: 12).

In the process of delivering writing instruction, the instructor primarily adopted Rose and Martin's (2012) SFL pedagogy: the students first learned one SFL construct through the relevant online resources before class, and they were then taught about the SFL construct in class. The students started learning SFL after finishing and submitting their first expository essay, prior to which they had to learn some macrostructures of expository writing (e.g., purpose, structure, and how to write a thesis sentence and body paragraphs). They completed the first round of SFL learning 
when they received the SFL-based teacher-written feedback on their first essay and when they started composing their second essay.

The teaching activities included reading and deconstruction of sample texts using SFL knowledge. The SFL constructs taught included register and ideational, interpersonal, and textual meanings, along with the corresponding lexical/grammatical manifestations. Each construct was taught for two weeks (four lessons for each construct on average). However, certain constructs (e.g., the appraisal system) took more than two weeks to teach, depending on the students' actual performances. In the first semester, the instructor taught the students the meaning-making features of the expository writing subgenres (e.g., cause and effect, comparison and contrast, and classification), and in the second semester, the teacher taught the students the meaning-making features of argumentative writing.

After the students' digital submission of their essays, the instructor gave the students written feedback in English on their essays. The teacher-written feedback was provided through written comments informed by the SFL-based constructs, and was provided in an indirect way (e.g., Can you watch the tone of your sentences? What do you think of the flow of the text?; see also section 3.1 below) to encourage the students to make independent revisions beyond structural grammar. The students submitted their revised essays based on the teacher's written feedback thereon.

All the student participants were informed of the purpose of the study before the commencement of the study, and expressed willingness to participate in the study. Three students who took both the expository and argumentative writing courses under the instructor were selected for an in-depth exploration in this study considering ethical issues and sample representativeness. They were willing to share their thoughts and their relevant written documents. Moreover, they were similar to the other students in the class and in larger EFL contexts as they believed that writing is largely a grammar-based activity. Thus, they were representative of the whole class and of larger EFL contexts, further justifying their selection as participants in the study. In addition, they had never encountered SFL through any reading material prior to the study, and they had never experienced receiving any relevant teacher-written feedback. These three female students were given the pseudonyms Elizabeth, Bella, and Mary for confidentiality reasons.

\subsection{Data collection and analysis}

Relevant data were collected by the researcher over one academic year. As the researcher was also the instructor responsible for the students' grades, he was constantly aware of the power relationship in the classroom and strictly followed the ethical standards of teaching. As the students' instructor, the researcher established a power-free relationship in and outside the classroom (e.g., he asked the students to 
call him by his first name; he would chat with the students during class breaks) so as not to contaminate the study data due to the presence of students who might have been influenced by the power structure in the classroom. In addition, to further mitigate the influence of the power differential on the students, when the students' grades were posted at the end of the semester, they were asked again about whether they consented to remain in the study, and they all agreed to remain in the study. Two graduate students also held discussions with the students concerning their narratives and in-class performances to make sure that the study data were not influenced by the teacher-student relationship.

The study data included transcripts of the interviews with the students, the students' written works (i.e., their essays and the revised versions of these, and their weekly reflections on their writing experiences in the classroom), the teacher's feedback on the students' essays, and transcripts of the teacher-student in-class conversations on writing. The researcher's field notes over one academic year completed the dataset. Interviews were initially conducted in the students' mother tongue (i.e., Chinese), and the transcripts of all the individual interviews of the students, which were approximately 10 hours long in all, were obtained. Over the academic year, four expository essays, three argumentative essays, and 16 reflection papers were assigned to the students. The reflection papers were written in either English or Chinese, depending on the student's preference, and the teacher provided written feedback on the students' expository and argumentative essays (35 or more items of SFL-based feedback per paper). The first two expository essays and the first argumentative essay involved two rounds of teacher-written feedback each. The third expository essay and the second argumentative essay, however, involved only one round of teacher-written feedback each as the students were expected to already be more capable then of regulating their writing at the level of meaning making. As the students were expected to have gained even more knowledge of SFL thereafter, very little feedback was given on the last essay in each course. As such, while teacherwritten feedback was provided on all the students' essays, the students' first three expository essays and first two argumentative essays (and their revised versions) were the key documents that were utilized in this study as they received the most intensive feedback and would potentially cast better light on the research questions (i.e., the focus of this study was on students' interactions with SFL-based instruction and teacher-written feedback).

The datasets included those whose original or source language was Chinese (the students' first language), such as the transcripts of the students' interviews. To ensure the accuracy of the analysis, the data were first transcribed in the original or source language. Based on the transcription, the data were primarily analyzed inductively (Eisner, 2017). The data were then translated into English for the international audience, and were eventually reported in the current paper. The themes were 
determined and condensed through vigorous comparisons. To facilitate theme retrieval, the initial codes were informed by the multi-layered SFL constructs (e.g., register variables and relevant linguistic features; see also section 1.1) as well as relevant literature on teacher-written feedback (Hyland, 2007; Lee, 2017). For example, the analytic codes for the students' essays and the teacher-written feedback included ideational, interpersonal, and textual meanings. They also included subcategories of these three dimensions of meanings, such as participant at the level of ideational meaning, engagement at the level of interpersonal meaning, and cohesive devices at the level of textual meaning. In addition, the researcher's field notes were examined to facilitate the analysis. To ensure external reliability, another experienced qualitative researcher also generously examined the whole process of data analysis and verified the study findings.

\section{Results}

Over the academic year, the students were able to overcome the challenges they encountered in the two writing courses they attended and embrace the SFL-based perspective on writing. The students transcended their previous knowledge limited to the grammatical level and understood writing construction as a meaning-making process. Such knowledge was mirrored in their writing practices. At the same time, the teacher-written feedback that the students received seemed useful. It interacted with the students' emerging knowledge and facilitated their understanding of SFL, guiding them in making revisions in their written compositions, although the power of teacher-written feedback did not take effect immediately or automatically across contexts. That is, the power of teacher-written feedback as a tool for knowledge enhancement was hampered by certain factors (e.g., knowledge base or generic expectations) over the two semesters spanned by this study.

\subsection{Updating one's knowledge about writing and receiving teacher-written feedback: Challenges and adjustment}

While the students did not resist learning SFL at first, they eventually experienced challenges due to the pedagogical contents of the relevant materials that were used. This can be seen in Bella's reflection below:

'When I read the easy material [related to SFL knowledge, such as textual meaning], I saw the usefulness of SFL . . . and I felt that the information on SFL from the online resources clarified my confusion regarding SFL as discussed in the textbooks . . . but when I read the difficult materials ... such as that on appraisal ... I needed to expend extra energy to understand them in and outside the classroom. It made me wonder, why should I learn SFL?' 
The students were frustrated with some of the knowledge provided by the materials, which were aimed at offering them a critical understanding of writing as SFL-based meaning construction. Such frustration seemed to be related to the challenges that the students encountered in digesting the linguistic knowledge related to SFL.

Meanwhile, in the initial phase of the first semester, when the students' knowledge of SFL was still underdeveloped, the SFL-based teacher-written feedback seemed not very helpful for their SFL knowledge enhancement and their writing practices beyond language form. This was especially true for the SFL-based teacher-written feedback on the first two expository papers (see Table 1).

Table 1. Features of the three students' writing practices and types of teacher-written feedback thereon.

\begin{tabular}{|c|c|c|}
\hline $\begin{array}{c}\text { Writing } \\
\text { types }\end{array}$ & Meaning-making features of the students' essays & $\begin{array}{c}\text { Samples of SFL-based } \\
\text { teacher-written } \\
\text { feedback }\end{array}$ \\
\hline \multirow{3}{*}{$\begin{array}{l}\text { First two } \\
\text { expository } \\
\text { essays }\end{array}$} & $\begin{array}{l}\text { Ideational meaning: This included the students' use of } \\
\text { colloquial words (culture-specific unelaborated lexical } \\
\text { choices). For example, when they mentioned Gao Kao, they } \\
\text { did not provide an additional explanation to tell the readers } \\
\text { that it is a high-stakes university entrance examination in } \\
\text { China. The students also inappropriately used genre-specific } \\
\text { choices of process (e.g., I think). Logical fallacies also } \\
\text { occurred when the students were presenting information. }\end{array}$ & $\begin{array}{l}\text { Ideational meaning: Are } \\
\text { these lexical choices } \\
\text { appropriate to the field in the } \\
\text { expository essay? Are the two } \\
\text { parts (i.e., claim and support) } \\
\text { logically connected to each } \\
\text { other? }\end{array}$ \\
\hline & $\begin{array}{l}\text { Interpersonal meaning: The students inappropriately used } \\
\text { personal comments/opinions as their supporting details at } \\
\text { the end of each body paragraph, such as we should... In } \\
\text { addition, information was presented too assertively; the } \\
\text { students did not use hedging resources. }\end{array}$ & $\begin{array}{l}\text { Interpersonal meaning: } \\
\text { Does the lexical choice hurt } \\
\text { the objective tone of the } \\
\text { expository essay? }\end{array}$ \\
\hline & $\begin{array}{l}\text { Textual meaning: The students' essays had isolated sentences } \\
\text { when providing supporting details. The students failed to } \\
\text { move from the general background to the thesis, resulting in } \\
\text { a lack of cohesion. }\end{array}$ & $\begin{array}{l}\text { Textual meaning: Can you } \\
\text { check the flow of the two } \\
\text { chunks? }\end{array}$ \\
\hline $\begin{array}{l}\text { Language } \\
\text { form in the } \\
\text { students' } \\
\text { essays }\end{array}$ & $\begin{array}{l}\text { The students' writing also had some grammatical errors, such } \\
\text { as inappropriate use of tense, collocations, punctuation } \\
\text { marks, and articles. }\end{array}$ & $\begin{array}{l}\text { Teacher-written } \\
\text { feedback: Can you double- } \\
\text { check the grammar bere? }\end{array}$ \\
\hline
\end{tabular}

Table 1 shows that beyond language form, the students were struggling with content representation at the level of meaning making. They also barely made satisfactory changes based on the teacher-written feedback they had received; the corrections made by the students were based only on the accessible feedback (e.g., Do you think you need a transitional verb here? Do you think there is a need for modal verbs here?). That is, the revisions were more related to one- or two-word corrections (e.g., the students added transitional words between two sentences in expository writing or added modal verbs in their claims in argumentative writing; field notes). A large scope of teacher corrections, such as those on the introductory paragraphs of the 
students' expository essays, was not well implemented (e.g., Your introduction needs to be rewritten as it is messy or as your supporting details do not match the tone of your claim; field notes). This suggests that the SFL-based teacher-written feedback, although in an accessible language, failed to benefit the students at the beginning of the first semester.

The students' failure to revise their essays based on the teacher-written feedback they had received beyond language form albeit their willingness to revise their essays accordingly seemed to have been related to their insufficient knowledge of writing. This can be seen in Mary's reflection when she was taking the expository writing course, as shown below:

'I saw non-grammar-related comments that I had never received before . . . It is not that I do not want to revise my essay based on such comments ... I just do not know what to do ... I want to be a better writer'.

The students did not intend to ignore the feedback they had received; they simply had limited knowledge to rely on when revising their essays based on the teacherwritten feedback they had received. Indeed, by the end of the first two months in the first semester, during which they wrote their first two expository essays, the students had just finished learning about SFL and had just gained basic knowledge of the SFLbased perspective on writing, which had not prepared them well for the corresponding writing practice and for revising their essays based on the teacherwritten feedback they had received.

Interestingly, the students were always responsive to the teacher-written feedback they had received on language forms in both semesters. This seemed to have been related to their prior learning experiences. As Elizabeth said:

'I have learned grammar for many years ... and I feel I am used to and like this type of feedback . . . also because my previous writing instruction was focused on accuracy.'

The students had formed deep concepts about writing as a form-based language activity due to their prior learning context. As such, they were already familiar with form-based feedback. For example, the students in the expository and argumentative writing courses immediately corrected their misuse of tense and prepositions in their subsequent writing drafts based on the teacher-written feedback they had received (field notes). Indeed, as Bella expressed in her reflection, 'I have a habit of trying to improve my grammar knowledge, hoping to receive relevant feedback, and making revisions ... so my writing can look good.' That is, to the students, grammar correction was a crucial gateway to successful English writing (Hyland \& Hyland, 2006). 


\subsection{Students' improved knowledge of SFL: Adapted use of materials and teaching}

With extended exposure to SFL-based learning, the students seemed to further embrace the SFL-based perspective on meaning making due in part to the multimodal instruction (e.g., the verbal channel from the teacher or the rearrangement of online materials). Bella recalled in an interview:

When the teacher explained to me the constructs . . . he would constantly help me with my first language . . or just lessen my stress by showing me the key features in an understandable language ... This made me better understand the purpose of the curriculum.

Similarly, in Elizabeth's reflection journals, she wrote:

Sometimes, following instruction, additional resources were sent to us, such as a video, which helped me further understand the constructs of the theory, such as the interpersonal meaning. . This made me understand the value of the SFL theory with regard to writing.'

Obviously, in addition to the pre-arranged materials based on his previous teaching experiences, the instructor provided accessible materials that were more befitting the students' levels. The instructor also mediated his students' learning using verbal strategies or additional visual materials. These multi-modal ways of mediation, to some extent, mitigated the students' frustrations with understanding the contents of the online learning resources while enhancing their engagement with the curriculum.

Over time in the first semester, the students' alignment with the SFL-based perspective on writing increased through their writing practices, where they experienced the analytic power of deconstructing texts and realized the usefulness of SFL in helping them improve their writing by making them focus on matters beyond what they had been taught to value (i.e., grammar). In other words, the students gained a more in-depth understanding of English discourse in general. For example, Elizabeth had the following realization after she deconstructed a sample essay in the expository writing class:

When we bring in the categories of graduation, attitude, engagement, etc., we can see the complexity of meaning within the framework of SFL rather than just randomly decoding texts or writing at the grammatical level and relying on general cognitive abilities, as we did before.'

During the in-class discussion of their own comparison-and-contrast essays on university and high school life (the third expository essay), the students well displayed their enhanced alignment with the SFL-based perspective on meaning making. The following is an excerpt of the conversation: 
Instructor: What do you think of the language resources in your writing?

Bella: What do you mean? Do you want me to comment on the language I used in my essay?

Instructor: Yes. How did you apply the knowledge that you gained from the relevant online resources to your writing?

Bella: Oh . . I see. For ideational meaning, for example, I focused more on the logical relationships between sentences or paragraphs. For example, I used more logical connectors, such as "however" or "different from university," when I talked about the different course arrangements between the two [university and high school]... In the past, I did not highlight the logical relationships or connections between sentences or paragraphs as I thought they were too obvious...

Instructor: You are making progress ... What else?

Bella: Also, I did not use some colloquial expressions... like "in this paragraph, I am going to focus on..." I used expressions that are more formal and used university life as the participant in some sentences...

Instructor: Great! By the way, do you think you have mood swings when you're writing your essay?

Bella: (Paused for a few moments) I used the word "impose" when I talked about how the curriculum in high school is implemented by teachers, but I used "freedom" when I talked about the course arrangement for university students. The two words actually showed my hidden stance in favor of university life.

Instructor: What a critical analysis... now you are developing (laughing with Bella).

The above conversation excerpt shows that the student could construct and analyze her essay from an SFL-based perspective. The students obviously no longer talked about grammar; they were already focusing more on the language features used for effective meaning construction (e.g., the use of logical connections, field-pertinent subjects, and implicit attitude) across the three dimensions of SFL, as instructed in class.

\subsection{Enhanced interaction between increased knowledge of SFL and teacher-written feedback}

With the students' increased knowledge of SFL, they seemed to more easily comprehend the teacher-written feedback they had received, which also further enhanced their knowledge of SFL and helped improve their writing the third expository essay). That is, the students expanded their knowledge of SFL through the 
teacher-written feedback they had received, and improved their writing by learning and applying the meaning-making process, which is expected in expository writing. To illustrate this, in the latter half of the semester, the students, in line with the teacherwritten feedback they had received, carefully molded the tone of their essays. Based on the teacher-written feedback she had received (i.e., Do you think you are too assertive?), Elizabeth replaced her lexical choice 'totally' with 'majorly' in the following sentence she originally wrote: 'The high school course arrangement is totally different from that in university.' The students also added cohesive devices in their expository essays based on the teacher-written feedback they had received. In her third classification essay, Mary added however' based on the teacher-written feedback she had received (i.e., Do you feel that there is any semantic transition missing between the parts?) when she wrote about how university life differed from high school life in China.

In all, the students were gradually able to improve their writing beyond language form due to the teacher-written feedback they had received. The students' essay revisions were not simply word- or phrase-level changes; they were made in conjunction with the contents (the three meanings) of the discourse (expository writing). As Mary realized in her reflection:

I felt the usefulness of SFL-based teacher-written feedback . . . This further reminds me or links with what I have learned in class ... in an indirect way, it provokes me to think again about how and why I did not well apply the SFL knowledge I had gained to my writing...

Echoing Mary, Bella also noted in an interview:

Thanks to the teacher-written feedback I receive, I do not pay attention only to accuracy; I think about what lexical and grammatical choices are appropriate in the context and text type to express writing contents or three meanings.'

The teacher's SFL-based feedback further enhanced the knowledge of SFL that the students had gained in class, effectively guiding them in writing better essays. Indeed, in their four expository essays, the students displayed meaning-making features well, which is expected in expository writing. For instance, at the ideational level, they demonstrated good logic among sentences. They learned to avoid the misuse of 'therefore' at the end of the body paragraph. At the interpersonal level, they also displayed good navigation of hedging language (e.g., 'some') and appropriate tone (e.g., avoiding the use of 'should' in the body paragraph). At the textual level, they also learned to use cohesive devices well, such as the use of 'among them' as a lexical resource to make a transition from the background information to the thesis sentence in the introductory paragraph. 


\subsection{Students' transition to the writing of argumentative essays: Temporary collapse and ultimate alignment}

When the students moved to argumentative writing in the second semester, notable issues emerged regarding the nuanced differences between genres, which posed challenges for the students in terms of their alignment with the online resources. As Mary recalled:

'As I studied SFL for a semester, I know that each genre has its own particular features while sharing common features with other genres... these unique features posed challenges... I could not do well in argumentative writing.'

The students' challenges concerned the interpersonal dimension. More specifically, when the students wrote counterarguments, they failed to effectively use the interpersonal resources. For instance, when partially countering an argument, Elizabeth did not know how to balance between attitudinal words, and she generally did not include appropriate engagement resources, such as the use of 'admittedly' to show partial negation of an argument (field notes). In the process of coming up with a counterargument, Bella also did not clearly show the boundary between her personal stance and the supporters' or opponents' arguments. Instead, she mostly incorporated citations from research, with no clue as to whether the author of the cited text was a supporter or an opponent of the claim that she mentioned (field notes). Indeed, the interpersonal resources in expository writing differ from those in argumentative writing because the genre of argumentative writing involves arguing, and one's personal stance is valued (Rose \& Martin, 2012). Meanwhile, similar to what they had experienced in expository writing, due to their insufficient SFL knowledge about argumentative writing, the students were not immediately able to apply the relevant teacher-written feedback on their first argumentative essays to their writing as they failed to revise their essays well based on such feedback. For example, although the teacher made comments on the missing use of engagement resources in the counterarguments in the students' first argumentative essays, no changes were made in that regard in the re-submitted versions of such essays (see Table 2). 
Table 2. Features of the three students' argumentative essays and types of teacher-written feedback thereon.

\begin{tabular}{|c|c|c|}
\hline Writing types & Meaning-making features of the students' essays & $\begin{array}{l}\text { Samples of SFL-based } \\
\text { teacher-written feedback }\end{array}$ \\
\hline \multirow{3}{*}{$\begin{array}{l}\text { First two } \\
\text { argumentative } \\
\text { essays }\end{array}$} & $\begin{array}{l}\text { Ideational meaning: The students mechanically and } \\
\text { constantly used show as the reporting verb rather than } \\
\text { changing it according to the strength of the evidence. } \\
\text { This involves the students' interpretation of evidence, } \\
\text { which sometimes amounted to a logical fallacy (e.g., } \\
\text { they did not take the research context into } \\
\text { consideration and made a hasty generalization). }\end{array}$ & $\begin{array}{l}\text { Ideational meaning: Is the } \\
\text { reporting verb appropriate for } \\
\text { expressing the meaning of the } \\
\text { original text? Does the research } \\
\text { really say so or suggest so? Can you } \\
\text { double-check the logic between the } \\
\text { evidence and your interpretation? }\end{array}$ \\
\hline & $\begin{array}{l}\text { Interpersonal meaning: The students did not navigate } \\
\text { information sources well when writing } \\
\text { counterarguments. For example, they did not use } \\
\text { engagement (e.g., XXX noted) to tell their readers that } \\
\text { the information that they presented is from an } \\
\text { external voice and is not from the author. The } \\
\text { students also misused adverbs in showing semantic } \\
\text { load (e.g., the inappropriate use of severely and } \\
\text { seriously when interpreting evidence) }\end{array}$ & $\begin{array}{l}\text { Interpersonal meaning: Do you } \\
\text { think you used engagement resources } \\
\text { well to tell your readers the source } \\
\text { and degree of reliability of your } \\
\text { information? Where is your stance } \\
\text { in the counterargument paragraph? }\end{array}$ \\
\hline & $\begin{array}{l}\text { Textual meaning: The students mechanically listed } \\
\text { research-based evidence in relation to a claim (e.g., } \\
\text { each study was introduced by according to XXX). } \\
\text { Cohesive devices, however, were well used. }\end{array}$ & $\begin{array}{l}\text { Textual meaning: Can you } \\
\text { double-check the flow of the two } \\
\text { studies you listed? Are they well } \\
\text { connected? Do you use transitions to } \\
\text { remind your readers of the boundary } \\
\text { between the opposing voice and your } \\
\text { own voice in the counterargument } \\
\text { paragraph? }\end{array}$ \\
\hline $\begin{array}{l}\text { Language form } \\
\text { in the students' } \\
\text { essays }\end{array}$ & $\begin{array}{l}\text { The students' essays also had some grammatical } \\
\text { errors, such as inappropriate use of the tense of } \\
\text { reporting verbs. }\end{array}$ & $\begin{array}{l}\text { Teacher-written feedback: Can } \\
\text { you double-check the grammar in the } \\
\text { sentence? }\end{array}$ \\
\hline
\end{tabular}

However, the students liked to utilize the teacher-written feedback they had received to reflect on their learning and improve their writing practices. As Bella realized when revising her first argumentative essay, 'I have been receiving SFL-based feedback for one semester, but when it comes to argumentative writing, it has its own features ... this bothers me and I need to figure it out.'

Similar to what the students had experienced in the expository writing course, the teacher's continued in-class teaching (e.g., verbal explanation of the purpose of argumentative writing and revisiting the purpose of argumentative writing in relation to the students' essays) helped the students better understand the SFL knowledge they had gained from the online resources and apply it to their argumentative writing. They were also able to enhance their SFL knowledge and application through the teacherwritten feedback they had received. The students' progress can be illustrated by Bella's later work in the argumentative writing course (starting from the second essay), along with the essays of the two other student participants. For example, at the interpersonal level in her argumentative essay, Bella supported her claim by citing the results of a study right after a counterclaim. Based on the teacher-written feedback she had 
received (i.e., Show your readers the boundary between your stance and others'), she then added an engagement resource (the supporters of this claim justified it by citing a recent study). Regarding textual meaning, the students also used cohesive ties in their argumentative essays to connect diverse studies (e.g., In a similar vein, resonating with the research) based on the teacher-written feedback they had received (i.e., Do you think the evidence is too mechanical? Can you connect the evidence and the claim?). Furthermore, based on the teacher-written feedback they had received, the students made revisions in their essays in terms of the logical relationships between claims and evidences. For example, when Mary mentioned the potential harm of drinking milk in her essay with only people's perceptions as evidence, based on the teacher-written feedback she had received (Do you think there is a logical relationship between your claim and the evidence?), Mary later provided evidence from an empirical study. As Elizabeth later realized in her reflection:

'The challenge is temporal and manageable ... Being exposed to the different genres of essays ... I realize the importance of having a flexible perspective on English discourses ... a and the essence of learning SFL lies in understanding the connections between the content, vocabulary/grammar, and meaning to achieve a particular purpose... We also cannot live without teacher-written feedback.'

In all, thanks to the in-class teaching of SFL and the SFL-based teacher-written feedback they had received, the students formed a more flexible perspective on writing while experiencing additional challenges from the demands of a different genre. This can be illustrated by the students' third and final essays respectively in the two semesters covered by this study. The meaning-making features in the students' argumentative essays were well aligned with the conventional features of effective argumentative writing. For instance, when the students were constructing ideational meaning, the verbs that they chose to use to represent information from an external source were not limited to 'show' but were varied according to the content of the source text, such as 'suggest', 'say', and 'claim'. Regarding interpersonal meaning, the students also used engagement resources, such as citation and phrasal expressions to help the readers differentiate the external voice from the authorial voice. Also related to interpersonal meaning in counterarguments, the students demonstrated the use of lexical and grammatical choices like 'while' and 'admittedly' to acknowledge the existence of other voices (i.e., opposing arguments) before starting their refutation of a claim. At the textual level, the students used lexical devices to connect research evidences, such as 'one study' and 'another research'. They also used grammatical choices like 'however' in making a transition from the acknowledgement of an external voice (i.e., an opposing argument) to their authorial voice (their refutation of the opposing argument). 


\section{DISCUSSION AND CONCLUSION}

This case study investigated how EFL students in a Chinese university interacted with SFL's perspective on meaning making and SFL-based teacher-written feedback over one academic year. First, in this study, the students experienced the value of SFL knowledge in helping them improve their writing. The students' understanding of writing was originally limited to language form, and the students had no knowledge of the meaning-making relationship between language form and meaning, which is expected in different types of writing. However, in a supportive context where instructional contents on SFL were scaffolded in class, the students gained meaningmaking knowledge in relation to writing. In this sense, this study was aligned with the previous studies on the teaching of SFL, showing that teaching SFL could help develop students' meaning-making awareness, which is needed for effective writing in either ESL or EFL contexts (e.g., Schleppegrell, 2004; Harman, 2018; Zhang, 2018).

Furthermore, in this study, the SFL-based teacher-written feedback further enhanced the students' knowledge about writing in the latter half of each semester while also preparing them for adjusting to the writing demands across genres. That is, unlike in the early phases, when they passively made revisions to their original essays, the students became capable of actively applying the teacher-written feedback they had received and the SFL knowledge they had gained to their writing, creating linguistically and meaningfully acceptable versions of their essays (e.g., controlling the text flow, reasoning logically, and including engagement resources). This finding echoes that of the previous studies suggesting a close relationship between students' writing practices, their knowledge about writing, and teacher-written feedback, with the three components constantly interacting with one another (e.g., Zhang, 2016). At the same time, however, in contrast to previous studies focusing on teachers' comments on students' language form (e.g., Lee, 2017), this study empirically illustrated how students interact with their SFL knowledge and with the teacherwritten feedback they receive, furthering the understanding of traditional instruction focusing on students' metalinguistic understanding (e.g., Fang, 2015; O’Hallaron et al., 2015; Harman, 2018) and answering the call to synergize meaning-based theory and teacher-written feedback to support students' writing development (Hyland, 2007). Indeed, the previous studies on teacher-written feedback created a 'false dichotomy' between language form and meaning (Hyland \& Hyland, 2006).

The current study also showed that students' positive experiences with writing gained in one context may not automatically lead to the same result in another context. In this study, the students who adjusted well to SFL-based teaching and teacher-written feedback in the expository writing course did not immediately become proficient writers in the argumentative writing course. This proves that developing students' writing abilities is not once for all; rather, it is temporary and text-typespecific, thus needing the help of teacher-written feedback. The complexity of 
students' writing development across genres can be due to the great conceptual load involved in adapting to meaning construction in different genres as each genre has its own specific characteristics (Harman, 2018), which means that students need additional time to develop such skill. In this regard, the current study illustrated the importance of teacher-written feedback across genres. While previous studies have shown the differences of cross-genre features and the affordances and challenges of raising students' cross-genre awareness through in-class teaching (Yayli, 2011; Qin \& Uccelli, 2016), little research has been conducted on students' response to SFL-based teacher-written feedback across genres. The findings of the current study complement the results of the previous studies on teacher-written feedback that were not conducted across genres, especially in EFL contexts (see Hyland \& Hyland, 2006 for a review; Zhang, 2016), furthering the understanding of student writers' dynamic adjustment patterns when navigating different genres aided by teacher-written feedback.

The implications of this study include the following. First, in addition to providing SFL instruction in writing class, teachers can provide feedback that will help their students revise their written compositions at the level of meaning making, thus assisting students in meeting academic challenges. To do this, promoting the pedagogical use of SFL (e.g., designing an SFL-based writing curriculum through online resources) in teacher education seems necessary in contexts where language form accuracy is favored, such as in China (Zhang, 2018). Second, students' interactions with SFL-based instruction and feedback involve a long and complex process that may cause emotional anxiety on their part. Given that students' lack of self-efficacy may negatively impact their writing and may cause them anxiety (Huerta, Goodson, Beigi \& Chulp, 2017), teachers are encouraged to offer their students emotional care or out-of-class assistance to help them learn the SFL-based perspective on academic writing. Most importantly, students' adjustments to the SFL-based perspective on writing can be hampered by generic demands in academic writing as each genre carries its own peculiar linguistic challenges. Therefore, feedback in conjunction with constant mediation on diverse genres should be provided to ensure students' academic success.

The limitations of this study cannot be ignored. The fact that the instructor/researcher already had professional knowledge of SFL made the design and implementation of the research convenient. Thus, other instructors intending to conduct a similar study need to gain SFL-based training or knowledge on their own through relevant materials (e.g., as shown in the Appendix section). 


\section{REFERENCES}

Carlino, P. (2012). Who takes care of writing in Latin American and Spanish universities? C. Thaiss., G. Bräuer., P. Carlino., L. Ganobcsik-Williams. \& A. Sinha, (Eds.), Writing programs worldwide: Profiles of academic writing in many places (pp. 485-498). Anderson, South Carolina: Parlor Press / WAC Clearinghouse [on line]. Retrieved from: http://wac.colostate.edu/books/wpww/chapter41.pdf

Eisner, E. W. (2017). The enlightened eye: Qualitative inquiry and the enhancement of educational practice. New York: Teachers College Press.

Fang, Z. (2015). Writing a report: A study of preadolescents' use of informational language. Linguistics \& the Human Sciences, 10(2), 103-132. DOI: 10.1558/lhs.v10i2.28556

George-Walker, L. D. \& Keeffe, M. (2010). Self-determined blended learning: A case study of blended learning design. Higher Education Research \& Development, 29(1), 1-13. DOI: 10.1080/07294360903277380

Harman, R. (2018). Transforming normative discourses of schooling: Critical systemic functional linguistics praxis. New York: Springer. DOI: 10.1007/978-3-319-60953-9_1

Huerta, M., Goodson, P., Beigi, M. \& Chlup, D. (2017). Graduate students as academic writers: Writing anxiety, self-efficacy and emotional intelligence. Higher Education Research \& Development, 36(4), 716-729. DOI: 10.1080/07294360.2016.1238881

Hughes, C. (2009). Assessment as text production: Drawing on systemic functional linguistics to frame the design and analysis of assessment tasks. Assessment \& Evaluation in Higher Education, 34(5), 553-563. DOI: 10.1080/02602930802187316

Humphrey, S. \& Macnaught, L. (2016). Functional language instruction and the writing growth of English language learners in the middle years. TESOL Quarterly, 50(4), 792-816. DOI: 10.1002/tesq.247

Hyland, K. \& Hyland, F. (2006). Feedback on second language students' writing. Language Teaching, 39(2), 83-101. DOI: 10.1017/s0261444806003399

Hyland, K. (2007). Genre pedagogy: Language, literacy and L2 writing instruction. Journal of Second Language Writing, 16(3), 148-164. DOI: 10.1016/j.jslw.2007.07.005

Lee I. (2017). Classroom writing assessment and feedback in L2 school contexts. Singapore: Springer. DOI: 10.1007/978-981-10-3924-9_7 
Martin, J. R. \& White, P. R. (2003). The language of evaluation. Basingstoke: Palgrave Macmillan. DOI: 10.15718/discog.2016.23.2.171

Moore, J. Schleppegrell, M. \& Palincsar, A. S. (2018). Discovering disciplinary linguistic knowledge with English learners and their teachers: Applying systemic Functional linguistics concepts through design-based research. TESOL Quarterly, 52(4), 1022-1049. DOI: 10.1002/tesq.472

O’Hallaron, C. L, Palincsar, A. S. \& Schleppegrell, M. J. (2015). Reading science: Using systemic functional linguistics to support critical language awareness. Linguistics and Education, 32, 55-67. DOI: 10.1016/j.linged.2015.02.002

Qin, W. \& Uccelli, P. (2016). Same language, different functions: A cross-genre analysis of Chinese EFL learners' writing performance. Journal of Second Language Writing, 33, 3-17. DOI: 10.1016/j.jslw.2016.06.001

Rose, D. \& Martin, J. R. (2012). Learning to write, reading to learn: Genre, knowledge and pedagogy in the Sydney School. Sheffield: Equinox.

Schleppegrell, M. (2004). The language of schooling: A functional linguistic perspective. Mahwah, NJ: Lawrence Erlbaum.

Taffs, K. H. \& Holt, J. I. (2013). Investigating student use and value of e-learning resources to develop academic writing within the discipline of environmental science. Journal of Geography in Higher Education, 37(4), 500-514. DOI: 10.1080/03098265.2013.801012

Taylor, I., Sánchez, M., Luzuriaga, M., Podestá, M. E. \& Furman, M. (2020). Marking classwork in primary science: Written feedback practices in state schools in Buenos Aires, Argentina. Assessment in Education: Principles, Policy \& Practice, 1 19. DOI: 10.1080/0969594X.2020.1729697

Tomlinson, B. (2003). Developing materials for language teaching. London, UK: Continuum. DOI: $10.5040 / 9781474211826$

Yayli, D. (2011). From genre awareness to cross-genre awareness: A study in an EFL context. Journal of English for Academic Purposes, 10(3), 121-129. DOI: 10.1016/j.jeap.2011.02.001

Zhang, X. (2017). Understanding Chinese EFL teachers' beliefs and practices in the textbookbased classroom. Bern: Peter Lang. DOI:10.3726/b11563

Zhang, X. (2018). Connecting OER with mandatory textbooks in an EFL classroom: A language theory-based material adoption. The International Review of Research in Open and Distributed Learning, 19(2), 89-110. DOI: 10.19173/irrodl.v19i2.3479 
Zhang, X. (2021). After-class academic support: Does course-embedded faculty tutoring matter to student writers? Teaching in Higher Education, 26(1), 129-144. DOI:10.1080/13562517.2019.1636223

Zhang, Z. (2016). Student engagement with computer-generated feedback: A case study. ELT Journal, 3(1), 317-328. DOI: 10.1093/elt/ccw089

\section{APPENDIX}

Web-based sample texts for argumentative writing

https://depts.washington.edu/owrc/Handouts/Hacker-

Sample $\% 20$ MLA $\% 20$ Formatted $\% 20$ Paper.pdf

Web-based sample texts for expository writing

http://ngl.cengage.com/assets/downloads/greatwi pro0000000335/gw5 unit6.pdf

Online resources for textual meaning and its construction

http://learningcentre.usyd.edu.au/clearer writing/module2/info structure intro.htm $\underline{1}$

Online resources for ideational meaning and its construction

https://www.youtube.com/watch?v=C3vdnuASwso

Online resources for interpersonal meaning and its construction

http://www.grammatics.com/appraisal/ 